\title{
International Legal Regulation of Russian-Iranian Cooperation in Energetics and Caspian Sea Delimitation
}

\author{
${ }^{1}$ Gulnara R. Shaihutdinova, ${ }^{2}$ Mohammadreza Malmir, ${ }^{3}$ Elmira N. Malmir \\ $1,2,3$ Kazan Federal University \\ Email: ildar_sh@mail.ru, mr.lawer2020@gmail.com,
}

\section{Received: 15th December 2017, Accepted: 20th December 2017, Published: 31st December 2017}

\begin{abstract}
The article is devoted to the history of contractual relations' development between Russia and Iran, dated back to XVI century. Particular meaning is given to the period stipulated by concluding of delimitation contracts between Russia and Iran concerning Caspian Sea, beginning on XIX century. It is important to note the capitulation contracts, marking Russian- Iranian relations in the period of reigned Russia and USSR. Currently, cooperation of Iran and Russia is appeared on different aspects with taking into consideration geopolitical situation, influenced on bilateral relations: labor power, natural resources, oil, gas, peaceful uses of atomic energy, inexhaustible energy sources, military and economic resources, export and import of goods. Intergovernmental agreements in the sphere of energetics are of key importance. 2017 year has become fruitful for contractual Russian-Iranian relations. Nowadays more than 300 contracts have been concluded known by authors of article from official resources. The list is not exhausted with this. For example, the agreement on cooperation in the sphere of peaceful uses of atomic energy stipulating the realization of nuclear technologies in medicine, agriculture and industry, fundamental researches in the sphere of nuclear physics was concluded in 1992.
\end{abstract}

Keywords: Energetics, Soviet-Iranian Relations, Field, Nuclear Energy, Peaceful Uses of Atomic Energy, Inexhaustible Energy Sources, The Caspian.

\section{Introduction}

The political situations and conflicts, happened for last 3 years in the world, directly concerning Russia, may say, have changed external conjuncture, and have oriented foreign- policy activities of Russia on active cooperation with eastern countries. Particularly, Moscow has paid attention on the Middle East represented by Islamic Republic of Iran. Peaceful uses of atomic energy, inexhaustible energy resources is non-exhaustive list on spheres for economic-legal cooperation with Iran, which is one of the top priority partner in this sphere.

In this regard the consideration of contractual relations between Russia and Iran in the sphere of energetics seem to be actual from scientific point of view. Issues on the delimitation of Caspian Sea which have been problematic from the times of reigned Russia and remain problematic nowadays are to be important and topical.

Issues on the delimitation of Caspian Sea have been considered by O.V. Glikman in the article «International agreements of Russia, regulating cooperation in oil and gas section», Guseinov V.A. in the monography «Caspian oi. Economics and geopolitics», Gabieva Z. in the article «Legal status of the Caspian». However, contractual economic relation of Russia and Iran in the sphere of energetics is poorly studied and represents main interest.

With reference to the above mentioned authors have determined the aim - to study contractual relations between Russia and Iran in the sphere of Caspian Sea. The aim has specified the following objects:

1. To consider the contractual relations concerning the delimitation of Caspian Sea from historical angle;

2. To ascertain the dynamics for solution of Caspian Sea delimitation problems;

3. To determine the actual list of contracts between Russia and Iran in the sphere of energetics.

\section{Methods}

Methodology of the article is based on the principles and categories of dialectics; induction and deduction. Historical analysis of agreements and contracts, concluded in the period from the end of XIX century, has given the option to determine the dynamics for the development of contractual relations between Russia and Iran in the sphere of Caspian Sea delimitation. In the process of research the actual materials about intergovernmental agreements in the sphere of energetics have been used from news Internet- resources in Russian, English and Persian.

\section{Results and Discussion}

2017 year marked the important anniversary of economic cooperation between Russia and Iran in the sphere of peaceful atomic energetics. Seminar called « 25 years of cooperation between Russia and Iran in the sphere of peaceful uses of atomic energy: new prospects in the framework of JCPOA (Joint Complex Plan of Actions)» has commemorated the anniversary [1].

Development of Russian - Iranian politic- economic relations starts from the beginning of Safavid dynasty (1501-1722). The first, who encouraged the 
initiation of relations between two countries, were Armenians.

Further the Qajar dynasty has ruled from 1795 to 1925. Rather this period marks the initiation of contractual relations between Iran and Russia: the contract «Legal status of Caspian Sea in the Golestan Agreement» was signed in 1813, Agreement «Khazar regime, based on the Agreement with Turkmenistan» was signed in 1928. Russian- Persian treaties has provided to Russia exclusive rights to have marine forces in the Caspian Sea forever.

It can be noted that reigned Russia accepted some methods of enslavement and exploitation of eastern nations [2]: it inequitable agreements capitulation ${ }^{1}$.

Persia has protected the right only for merchant shipping. It has meant the full subjection of Caspian Sea to Russian jurisdiction. Providing clearer, the Caspian was considered as inner (intracontinental) reservoir of Russia, not as the international sea or international lake.

Soviet Russia gave up on monopoly rights for the Caspian and termless soviet-Iranian agreements (1921, 1935 and 1940) have determined equal and exclusive rights for carrying-out marine activity on the Caspian Sea of two Caspian bordering countries - USSR and Iran.

28 February 1921 the government of Russian SFSR signed the agreement with the Persia [3], which cancelled all agreements concluded by reigned government before, including Treaty of Turkmenchay 1828 [4]. The right of Persia for free navigation on Caspian Sea has been acknowledged. And in the Treaty there were no any other reference on delimitation of Caspian water.

27 October 1931 the Convention on settlement, trade and navigation between USSR and Persia was signed. It declared the exclusive rights only for USSR and Persia ships to navigate.

By the Treaty between USSR and Iran on settlement, trade and navigation [5] dated by 1935 the coastal zone of ten miles has been ascertained [6].

Rather this thesis was confirmed in the Treaty between USSR and Iran dated by 25 March 1940 on trade and navigation [7]. It was emphasized again that only the ships of USSR and Iran have the privilege to navigate in the Caspian Sea. However there were no any certain provision on delimitation of the Caspian Sea that made the difficulties in borders' protection.

Utterly on a unilateral basis in 1935 the Soviet Union accepted the line Qasan - Quli (Turkmenistan) Astarachay (Azerbaijan). Widely used term «Soviet-

\footnotetext{
${ }^{1}$ Capitulatory regime has provided exclusive prerogatives for capitalists of European countries: providing the right of domicile, free movement; guaranteeing the immunity of personality and residence, and also confiscation of their activity from civil and criminal jurisdiction of local courts; providing the right for freedom of trade.
}

Iranian Sea» has meant that these two states, their organizations and citizens had the right for navigation.

Closeness of the Caspian Sea for the third countries was clearly set in the article 14 of the Treaty dated by 1935 which proclaims that «Along the entire length of the Caspian Sea only the ships, obtained by USSR and Iran has the right to use the Sea, as well as equally the citizens and trade transport organizations of one of Contracting Party, navigating under the flag of USSR or under the flag of Iran accordingly. They equally agree on to have among the crew only those bodies who are the citizens of their state».

Beginning from 1934 both Parties kept the conventional border by water and by air in the line of Astara - Qasan -Quli. And this marine border which was officially unregistered became mutually observed «legal» regulation in the Soviet - Iranian Caspian relations.

From other side, the Law about state border of USSR dated by 1982 claims that state border of USSR, if other is not stipulated by the international agreements of USSR, is established «on rivers and other reservoirs by the direct line, joining exits of state borders of USSR to lakes and other reservoirs' coasts». Therefore, this law has divided the Caspian Sea between USSR and Iran by lake status without any permission of Iran [8].

It also should be noted that over a period of SovietIranian jurisdiction of the Caspian Sea (1921-1991) not all problems were regulated. Fishing zone of 10miles not always has been considered as the border of two countries' sovereignty.

For example, from 1949 USSR without coordination with Iran and in violation of the thesis «equal rights» actively produced oil at a distance of zone in 10-miles, which is current Azerbaijanian branch.

Later Iran conducted marine oil extraction in Enzeli district (Pehlevi) [6].

After that with the dissolution of the Soviet Union, the Caspian Sea and its natural resources became a source of contention for Russia, Iran, Azerbaijan, Kazakhstan, and Turkmenistan [9].

Currently all Caspian governments arrived at agreement $^{2}$ on protection of the Caspian Sea environment (corresponding Convention was accepted in 2003). In 2012 the Protocol on regional readiness, response and cooperation in the case of incidents causing the pollution by oil, directed on creation of the regional mechanism and the plan of regional cooperation was developed. Also Caspian governments agreed on the cooperation in the sphere

\footnotetext{
2 According to Intergovernmental economic conference of Caspian governments the Caspian Sea passes over the shores of five inshore governments: Kazakhstan, Iran, Turkmenistan, Russia and Azerbaijan
} 
of security (corresponding agreement was accepted in 2010). At last document Caspian governments have confirmed all exclusive rights in ascertainment and development of Caspian legal status. This treaty confirms that providing security in the Caspian region is the prerogative of Caspian governments. The energetics was not included into the list of cooperation, however, it included providing security of marine navigation and fight against the piracy, and also the providing of security for navigation. It is important to stress that the list pointed at this treaty is not closed. Within this treaty the Parties conduct the cooperation in other spheres corresponding to the subject of current treaty and representing mutual interest, apart from military aspects of security.

Consequently, concluding delimitation agreements between Caspian states testifies that from the legal point of view there is no continental shelf, so inshore governments and other states don't have the right for exploration, resource development and undersea cable and pipeline routing, stipulated in United Nations Convention on the Law of the Sea dated by 1982. The goal of delimitation agreements on Caspian Law is also in strengthening of bilateral mechanisms for cooperation on hydrocarbon exploration and extraction [10]. Nonetheless as the results we see that conflicting interests have caused the inability to reach an agreement on the legal status of the body of water, led to its militarization; and caused the conflict over the exploitation and transportation of oil and gas [11]. However, there is also the positive side in solving the problem of conflicting interests which in recent times has increased the stability.

Issue concerning the Caspian Sea has always been and remains topical and alarming issue for all. However it doesn't interfere with establishing and development of productive economic-legal relations, particularly, in the sphere of energetics.

Nowadays cooperation between Iran and Russia appears in different aspects with taking into consideration geopolitical situation, which has the influence of bilateral relations: labor power, natural resources, oil, military and economic possibilities.

With an eye toward the realization of economic possibilities the following intergovernmental agreements between Russia and Iran in the sphere of energetics were introduced for consideration and signing:

- Treaty on cooperation in the sphere of peaceful uses of atomic energy, providing variety of ways: usage of nuclear technologies in medicine, agriculture and industry, fundamental researches in the sphere of nuclear physics and etc.

- Treaty on completion of building the first APS unit in Bushehr (1995). The construction works of Bushehr APS have started in 1998. Further the Protocol about compulsory reversion of atomic fuel from Bushehr APS into Russia was signed (27.02.2005).

- Joint Comprehensive Plan of Action (JCPOA) was signed on 14 July 2015 after several continuous sessions. JCPOA is Iranian agreement with the $5+1-$ the five permanent members of the UN Security Council, namely United States, Russia, China, United Kingdom and France, plus Germany - in November 2013 [12]. Signing of this document has created conditions for presence of huge amount of international European organizations in the territory of Iran.

- Treaty of construction of eight atomic power generating units is the biggest deal in world atomic market for the last years, which will produce not only more than 10 milliards of dollars, but will also provide consolidation of its political positions in Middle-East region. 300 Russian companies serve Russia-Iranian interests.

Trends, pointed by the President Vladimir Putin during forum «Russian energy week», determine trends for the development of further cooperation between Russia and Iran in the sphere of energetics. These trends are the following: shift of energy demand to Asia-Pacific region; digitalization of economy; implementation of smart electricity grid; increasingly large role of carbohydrates; growth of inter fuel competition; pure energetics and renewable sources; modernization of energy processing companies; development of pure atomic energy; modernization of solar panels with the implementation of update domestic technologies [13].

There are a lot of examples of cooperation activation between Russia and Iran. For instance, «Gazprom neft» takes interest in joint work with Austrian oil and gaz company OMV in the oilfield Band-eKarheh in Iran. Also the company is interested in conducting joint work in the oilfield Azar in the partnership with Iranian company OIEC (Oil Industries' Engineering and Construction). Gazprom has already signed the Treaty on cooperation with above mentioned company. Apart from oilfield Azar the Parties have also agreed on exploitation of Shangule oilfield [14].

Iran also expresses interest to Russian companies. Iran has already concluded preliminary agreements with six companies: «Gazprom», «Lukoil», «Gazprom neft», «Rosneft», «Tatneft», «Zarubezhneft». Till March 2018 Iran plans the deals on the projects Azadegan, Ab Teymour, Mansouri, Yadavaran with overall efficiency $2 \mathrm{mln}$ barrel per day. Currently, Iran also develops new contract type - Iran Petroleum Contract, IPC. Its main difference is in providing the possibility for investors to have participation in the project and to 
participate in production sharing. The contract terms were increased till 20-25 years [15].

Among Russian - Iranian projects there is the project between Rosgeology ${ }^{3}$ and National Iranian Oil Company (NIOC), which concluded the Memorandum of understanding on 28 March on the results of negotiations between the presidents of Russia and Iran in Moscow [16].

Development of gas field «Kish Gas Field ${ }^{4}$ on Kish Island is conducted. Arrangements between oil and gas multinational corporate group «Royal Dutch Shell», Italian energy giant «Eni», Russian «Gazprom» and Iranian firms including investment company «Gadir», affiliated company «Bank Saderat Iran» and investment company «Sanne Yekta» [17] have been already reached.

The Road map between Russia and Iran in the sphere of energetics was signed in Saint-Petersburg on economic forum. From Iranian party the signatory was the ministry of energy Bizan Namdar Zangene. Construction of electro stations in Iran, which provide gas, electricity, water and petrochemistry services, is planned with the participation of more than 10 thousand Russian firms [18].

In the course of several meetings with Iran, conducted in the territory of Russia on autumn 2017 , some arrangements in the sphere of energetics were reached. Particularly, the Memorandum of Understanding concerning investing of Russian firms to Iran with further initiation of parliamentary group in the sphere of energetics was signed on the meeting of Committee of State Duma on energetics (Russia) and Iranian Parliament Commission on Energy under Islamic Consultative Assembly [19]. The parties have also discussed the collaboration in the sphere of nuclear energy.

Current exasperation of political situation with regard to unilateral statement of USA about the intention to pull out of the «nuclear deal» became the key topic. According to both parties opinion the deliberate escalation of tension from USA as well as all sanction policy of this state is dictated by economic motive. This doesn't really contribute to safety back-up in the region and world at all [20].

Subsequent to the results of «Rosneft» and National Iranian Oil Company (NIOC) the road map on realization of strategic projects in the sphere of oil and gas production in the territory of Iran was made. In the nearest future the Parties may sign several binding agreements which will let to invest into joint petroleum projects with total sum 30 milliard dollars. Not only «Rosneft» pretends to Iranian mineral resources - «Lukoil» contemporaneously negotiated with NIOC about absorption of two oil fields - Mansouri and Ab-Teymour. These are the

\footnotetext{
${ }^{3}$ Rosgeo is Russian multi-industry geology holding company, providing full range of services, connected with geological exploration. $100 \%$ of capital is state-owned assets
}

largest oilfields, each has more than 1 milliard tonne of mineral resources [21].

The role of signing treaty on cooperation between the Industrial Development and Renovation Organization of Iran (IDRO) and Economic Development Board of the Russian Federation should be also mentioned. This treaty provides turbine, generators, solar batteries, repair parts and civilian helicopters delivery [22].

In the beginning of November 2017 the President Vladimir V. Putin visited Iran and had the meeting with the President Hasan Rouhani. The Parties have discussed the fight against terrorism, peace and stability in the Middle East, and also the questions on construction of electro stations and railways. New treaties in the sphere of tourism, sport and trade are aimed at strengthening of two countries cooperation [23].

\section{Summary}

For all history of Russia and Iran their cooperation may be characterized as

Double -natured: it has its own negative and positive sides. The peculiarity of relations during reigned Russia, and also Soviet-Iranian relations is the existence of unequal treaties, capitulatory regime, attempts to set trade navigation, unequal delimitation of Caspian Sea. The last issue is actual up to now. Importance of delimitation treaties on Caspian Sea consists in establishing bilateral mechanisms of cooperation on hydrocarbon exploration and production.

Prior for the whole world direction - hydrocarbon exploration and production - forms interfuel competition between oil countries - leaders. For the last 5-8 years productive partnership between Russia and Iran was set up, in which leading Russian companies such as «Gazprom», «Lukoil», «Gazpromneft», «Rosneft», «Tatneft», «Zarubezhneft» and large Iranian companies such as OIEC (Oil Industries' Engineering and Construction), NIOC (National Iranian Oil Company), IDRO (Industrial Development and Renovation Organization of Iran) played not the last role. Treaties between abovementioned companies concern important strategic projects, the realization of which has started or only is going to be realized on Iranian oilfields Mansouri, Ab-Teymour, Azadegan, Yadavaran, Bande-Karheh, Kish, Azar, Shangule.

Important fundamental intergovernmental treaties in the sphere of energetics are worthy of attention. They are: Treaty on cooperation in the sphere of peaceful uses of atomic energy (1992); Treaty on completion of building the first APS unit in Bushehr (1995); Joint Comprehensive Plan of

\footnotetext{
${ }^{4}$ Opened in 1968, gas field Kish is located in $30 \mathrm{~km}$ eastwards from the island Lavan in the Persian Gulf. 1.3 cubic $\mathrm{m}$ of natural gas and more than $500 \mathrm{mln}$ barrel of gas-condensate, ultralight kind of oil is located on this field.
} 
Action (JCPOA) (14 July 2015); Treaty of construction of eight atomic power generating units

\section{Conclusion}

2017 year productive for conducted negotiations and concluded agreements let to build big plans for nearest future, to conduct constructive dialogue with Iran. The official reports of IAEA (International Atomic Energy Agency) confirm that Iran applies the undertakings entirely. This increases the confidence in wellbeing of cooperation with Iran. «Russia is guided by these reasons and will encourage the deal, which was concluded to the previous administration of United States», concluded President Vladimir V. Putin during his speech on international forum «Russian energy week» [13].

\section{Acknowledgements}

The work is performed according to the Russian Government Program of Competitive Growth of Kazan Federal University.

\section{References}

[1] Atomic Energy Organization of Iran. Iran Russia nuclear cooperation seminar held in Moscow. URL:

http://www.aeoi.org.ir/portal/home/?news/45799/6 9280/250290/Iran-\%E2\%80\%93-Russia-nuclearcooperation-seminar-held-in-Moscow

[2] NII Monopoliya vneshney torgovli. Torgoviyu otnosheniya SSSR so stranami Blizhnego Vostoka. - Moskva: Izd-vo v/o «Mezdunarodniya kniga», 1938 [in Russian]

[3] Zakoni Rossii. Dogovor mezdu Rossiyskoi Socialisticheskoi Federativnoi Sovetskoi Respublikoi I Persieye (podpisan v g. Moskve, 26.02.1921). $\quad-\quad$ URL: http://www.lawrussia.ru/texts/legal 767/doc767a55 8x825.htm [in Russian]

[4] Turkmachaiskiy mirnyi dogovor mezdu Rossiye I Iranom. 10.02.1828. - URL: http://www.hist.msu.ru/ER/Etext/FOREIGN/turkm an.htm [in Russian]

[5] Guseinov V.A. Kaspiyskaya neft. Ekonomika I geopolitika. - Moskva: OLMA - PRESS, 2002

[6] Gabieva Zarina. Pravovoi status Kaspya. - URL: http://observer.materik.ru/observer/N8_2004/8_12. HTM [in Russian]

[7] Zakoni Rossii. Dogovor o torgovle I moreplavanii mezdu SSSR I Iranom (podpisan v g. Tegerane 25.03.1940). - $\quad$ URL: http://www.lawrussia.ru/texts/legal 517/doc517a72 5x895.htm [in Russian]

[8] Zakon SSSR ot 24.11.1982 «O gosudarstvennoi granize SSSR». - URL: http://zaki.ru/pagesnew.php?id=1855 [in Russian]

[9] Hanna Zimnitskaya, James von Geldern. Is the Caspian Sea a sea; and why does it matter? - Journal of Eurasian Studies 2 (2011) 1-14

[10] Glikman O.V. Mezdunarodniyi dogovori Rossii, reguliruyushii sotrudnichestvo $\mathrm{V}$ neftegazovom sektore. - Jurnal rossiyskogo gazovogo obshestva «Gazoviy biznes». - URL: www.gazo.ru [in Russian]

[11] Davor Boban, Karlo Loncar. Geopolitical consequences of resolving the legal status of the Caspian Sea: security and energy aspects. Hrvatski geografski glasnik, Vol.78 No.2 Siječanj 2017.

[12] Anthony H. Cordesman, Bryan Gold, Chloe Coughlin - Schulte. Iran- sanctions, energy, arsm control, and regime change. Center for strategic and international studies, January 2014.

[13] Rossiyskaya energetichiskaya nedelya. - URL: https://www.youtube.com/watch?v=bQ1JWegVYD w [in Russian]

[14] Bank dannih. Ekonomichiskii svazi Irana I Rossii. «Gazprom neft» proyavlyaet interes k rabote na mestorojdenii Band-e Karheh v Irane. - URL: http://ru.irrutrade.ir/news/detail/--171-Газпромнефть--187--проявляет-интерес-к-работе-наместорождении-Банд-е-Кархех-вИране/1859/view/ [in Russian]

[15] Nationalniy otraslevoi jurnal. Neftegazovaya vertical. Iran podderjit prodleniye sdelki OPEK + posle marta 2017 goda. - URL: http://www.ngv.ru/news/iran_podderzhit_prodlenie sdelki_opek_posle marta 2018 goda/?sphrase id $=8692295$ [in Russian]

[16] Nationalniy otraslevoi jurnal. Neftegazovaya vertical. Rosgeologiya vedet peregovori $\mathrm{s}$ neftanikami po sovmestnoi realizazii proektov $\mathrm{v}$ Irane. - - URL: http://www.ngv.ru/news/rosgeologiya_vedet_pereg ovory_s_neftyanikami_po_sovmestnoy realizatsii proektov_v_irane / [in Russian]

[17] PressTv. Iran, Turkey, Russia sign oil, gas investment deal. URL: http://www.presstv.com/Detail/2017/08/09/531206/ Iran-Russia-Turkey-oil-gas-investment-deal 
[18] News agency Mehr. Signing of Road map of cooperation between Iran and Russia in the sphere of energetics. - URL: http://www.mehrnews.com/news/3995463/, translation from Persian.

[19] Sait Komiteta Gosudarstvennoi Dumi po energetike. Komitet Gosudarstvennoi Dumi po energetike I Komissiya po energetike Madjlisa Islamskogo Soveta Irana dogovorilis o sozdanii sovmestnoi rabochei gruppi po voprosam energetiki. - URL: $\quad$ http://www.komitet213.km.duma.gov.ru/Mezhdunarodnoesotrudnichestvo/item/14500456/\#top [in Russian] [20] News agency of Islamic Republic IRNA. Iran and Russia have agreed on initiation of joint parliamentary group in the sphere of energetics. URL:

http://221955921.r.afracdn.com/fa/News/82698278 , translation from Persian, free access

[21] Elektronnya gazeta «Vedomosti». «Rosneft» ozenila budushii investizii $v$ Iran. - URL: https://www.vedomosti.ru/business/articles/2017/1 1/01/740205-igor-sechin-nashel [in Russian]

[22] Informazionni sait Pars Today. Posol Rossii v Tegerane: «RF namerena razvivat economic svazi s Iranom».

URL: http://parstoday.com/ru/news/iran-i74987 [in Russian]

[23] Telekanal Mir24. Vizit Putina I Alieva v Iran: itogi. - URL: https://mir24.tv/news/16275465/vizitputina-i-alieva-v-iran-itogi

[in Russian] 